\title{
ITINERARIO DE MONUMENTALIZACIÓN Y CAMBIO DE IMAGEN EN COLONIA PATRICIA (CÓRDOBA) *
}

\author{
POR
}

\author{
PILAR LEÓN ALONSO \\ Universidad de Córdoba
}

\section{RESUMEN}

La configuración de la imagen de una ciudad como la Córdoba romana es fruto de su propia evolución histórica y, en consecuencia, de circunstancias en buena parte imprevisibles. Pero también lo es de la planificación y de la elección hechas por los responsables de la actividad edilicia. La proyección de la imagen urbana depende de la conjunción de ambos planos y sólo la amplitud de miras pretende elevarla a categoría de monumental. La trayectoria de la Córdoba romana así lo manifiesta.

\section{SUMMARY}

A Roman town like Cordoba is the result of its own historical evolution and consequently of unpredictable circumstances; but also it is the result of the planning and the choices made by those responsible for the aedilitian activity. The projection of the urban image depends on both factors. The trajectory of the Roman Corduba is a clear example of it.

La monumentalización de una ciudad romana provincial es un proceso itinerante, en el que las sucesivas estructuras históricas representan ciclos. La secuencia de imágenes que la ciudad ofrece en cada uno de éstos es indicativa de su capacidad de adaptación al hecho inexorable del paso del tiempo y de su capacidad de reacción ante el poder fáctico de los acontecimientos. La variedad es mínima, salvo en circunstancias excepcionales, a causa del común denominador impuesto por Roma y a causa del comportamiento similar de las élites locales.

Entre las ciudades hispanorromanas, la capital de la Bética, Colonia Patricia, ilustra ejemplarmente la situación. Como punto de partida es importante distinguir tres entidades o estructuras históricas -Corduba republicana, Colonia Patricia y Corduba bajoimperial-, cuyo análisis arqueológico resulta sumamente instructivo, tanto a la hora de descifrar las claves del proceso de monumentalización como de renovar la idea de provincial.

* Agradezco a J. F. Murillo su crítica y comentarios al trabajo, así como las figuras que ilustran el texto. A A. Peña la corrección del manuscrito.
La primera imagen de la Córdoba romana está fuertemente marcada por la irregularidad de su planta, rasgo que se observa en buen número de asentamientos romanos de época republicana ${ }^{1}$ (fig. 1). En el caso de Corduba esa irregularidad es consecuencia del intento de implantar la idea de esquema campamental en una topografía abrupta, pero adquiere, además, un significado desde el punto de vista de la imagen. La fundación de M. Claudio Marcelo, cuya cronología se sitúa en el segundo cuarto del siglo II a. C. ${ }^{2}$, ocupó una terraza elevada sobre el Guadalquivir, en la que barrancos y arroyos constituyen defensas naturales para sus flancos. No obstante, la ciudad, cuya superficie alcanzaba 47 Ha. contó pronto con murallas ${ }^{3}$, elemento representativo por excelencia de un status sólido y preludio de aspiraciones en cuanto a monumentalidad, como ha demostrado P. Gros ${ }^{4}$. En relación con la imagen conviene subrayar la importancia que adquieren tensión y contracción en la línea de contorno, pues, cuando se observa la planta, se tiene la impresión de que éste es el único indicio a través del que se puede intuir la conciencia que la ciudad tuvo de su propio destino desde un principio. Se diría que ese propugnaculum poligonal y cerrado se sabía llamado a ser caput provinciae, tanto para el desarrollo de operaciones militares como para el control del vasto y rico territorio circundante. Desgraciadamente no es mucho lo que se puede añadir para completar esa imagen, aunque en el estado actual de la investigación se pueden dar algunos datos por seguros.

1 J. R. Carrillo y otros, «Córdoba. De los orígenes a la Antigüedad Tardía», Córdoba en la historia: la construcción de la urbe (en prensa), 28 fig. 2.

${ }^{2}$ Sobre los pormenores de la fundación, ibid. 26 ss.; A. U. Stylow, «De Corduba a Colonia Patricia. La fundación de la Corduba romana», en: P. León (ed.), Colonia Patricia Corduba. Una reflexión arqueológica, Sevilla, 1996, 77 ss.

3 A. Ventura y otros, «Análisis arqueológico de la Córdoba romana», en: P. León (ed.), cit. (n. 2) 90 ss. A. Ventura, P. León, C. Márquez, «Roman Cordoba in the light of recent archaeological research», en: S. Keay (ed.), The Archaeology of early Roman Baetica, JRA Suppl. 29, 1998, 89.

${ }^{4} \mathrm{P}$. Gros, L'architecture romaine 1. Les monuments publics, Paris, 1996, 43 ss. Carrillo y otros, cit. (n. 1) 28. 
Aspectos decisivos en la planificación urbana fueron el trazado de la red viaria y la configuración de un espacio público, libre y abierto. La red viaria se articula a partir de un eje longitudinal N-S -el cardo máximo- en cuyos extremos se abrieron puertas. Mayor complejidad tiene la definición del eje E-O, pues, según ponen de relieve investigaciones recientes ${ }^{5}$, no parece que se concediera prioridad a un decumano sino a dos, cada uno de los cuales ostentaría una puerta en su extremo. El desdoblamiento del eje transversal E-O, atestiguado en ciudades itálicas ${ }^{6}$, no deja de ser notable; a falta de otra explicación por el momento, cabría pensar que refuerza el carácter emblemático del espacio reservado al foro, como si de un doble filtro se tratara respecto al tráfico proveniente del $\mathrm{S}$, intenso muy posiblemente por la proximidad del río; por otra parte, actuaría como distribuidor en pleno centro urbano y despejaría posibles aglomeraciones en la zona más respetable y digna de la ciudad. El sector norte de la terraza se configura así como el más distinguido y privilegiado, de ahí que se convirtiera también en el más monumental. Aunque la información disponible es sumamente parca, sabemos que a la altura de la intersección del cardo máximo con el más septentrional de los decumanos mencionados estuvo el foro. La intensa remodelación de la zona en época augustea, exigida por la construcción del foro de la Colonia Patricia, ha borrado en gran medida los vestigios del viejo foro republicano de Corduba. Del esquema imperante en la época y de algunas observaciones arqueológicas se infiere que lo atravesaba el cardo máximo; en cuanto a posibles edificios representativós relacionados con él, sólo cabe suponer su existencia en función del esquema tradicional y de algunas noticias literarias ${ }^{7}$.

Más convincente y seguro es el conocimiento que hoy se tiene sobre la arquitectura doméstica de la primitiva Corduba, gracias a la información obtenida en excavaciones fiables. El panorama, que éstas descubren, alude a sencillez e incluso perentoriedad tanto en técnica como en materiales de construcción. Encontramos, así, guijarros y adobes para los muros, cal y tierra batida para los pavimentos, madera y entramado vegetal para las techumbres. La organización del espacio interno de estas casas no nos es tan bien conocida, pero parece afín a la de estructuras domésticas coetáneas, como por ejemplo las de Italica; curiosamente en ambos casos se han constatado pequeñas instalaciones industria-

\footnotetext{
${ }^{5}$ Ibid. 28 ss

6 Ibid.

7 C. Márquez, La decoración arquitectónica de Colonia Patricia, 1998, 174.
}

les - un horno cerámico en Italica, un taller metalúrgico en Corduba- en algunas casas ${ }^{8}$. Por lo demás, sólo es posible consignar la orientación cardinal de los muros y la alineación de las casas. Si a estos datos se añade la abundancia en ambientes domésticos de cerámicas importadas - campanienses, ánforas itálicas, lucernas-, en contraste con la presencia insignificante de cerámicas indígenas, cobran relieve el carácter itálico y la ascendencia romana del modus vivendi generalizado en la fundación de Marcelo.

En poco más de dos generaciones, hacia finales del siglo II o comienzos del i a. C., la ciudad da el primer paso hacia un proceso de monumentalización (fig. 2). Las excavaciones realizadas durante los últimos años en la zona correspondiente al límite meridional de la ciudad republicana ilustran con claridad los pormenores de dicho proceso ${ }^{9}$. Consistió éste en una regeneración de imagen tanto a nivel público como privado, probablemente inducida por la consolidación del status político de capital de Hispania Ulterior y por el consiguiente deseo de querer exhibirse como tal. Nada hace pensar que se debiera a improvisación, antes por el contrario, el hecho de que la zona más afectada por la remodelación fuera el sector meridional de la ciudad, fácil de desmontar al estar ocupado por las modestas casas del periodo fundacional, indica que era una actuación programada. Lo más interesante en ella es la búsqueda de equilibrio en el esquema urbanístico, esto es, la intención de dar «pendant» al sector septentrional, en el que se ubicaba el foro.

La remodelación supuso la construcción de un edificio público, probablemente un templo, anejo a otro espacio abierto. Así lo da a entender el potente relleno de un posible podio pavimentado con grandes losas de arenisca, bajo el que corría una cloaca adintelada. A esta estructura se asocian restos de fustes de columnas y de un capitel dórico-toscano, igualmente de arenisca, cuyo inmediato paralelo se tiene en el foro republicano de Ampurias ${ }^{10}$. Con ser esta adquisición importante, las nuevas obras sirvieron, además, para renovar y dignificar el acceso a la ciudad por el $\mathrm{S}$, al tiempo que se dotaba de nuevos referentes visuales al eje cardinal de la ciudad, el más valorado sin lugar a dudas en época republicana. Como medida complementaria se pavimentan

${ }^{8}$ P. León, «Hacia una nueva visión de la Córdoba romana», en: P. León (ed.), cit. (n. 2) 19 ss. Ventura y otros, cit. (n. 2) 90, fig. 5-6. J. R. Carrillo, «Evolución de la arquitectura doméstica en Colonia Patricia Corduba», Córdoba en la historia: la construcción de la urbe (en prensa), 61 ss.

9 Ibid. 88 ss.

${ }^{10}$ Márquez, cit. (n. 7) 179. Carrillo y otros, cit. (n. 1) 31. 


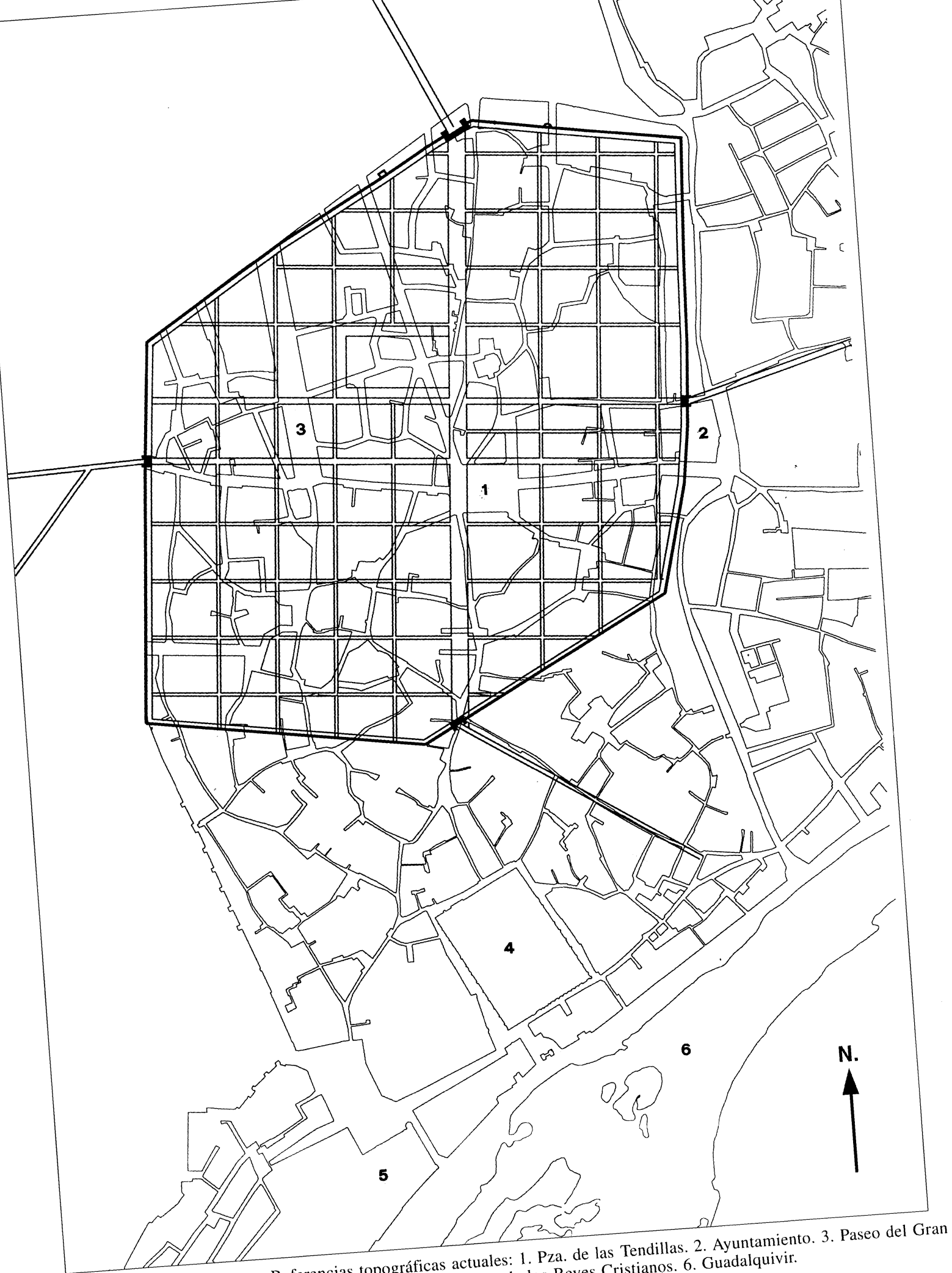

(on Reyes Cristianos. 6. Guadalquivir.

Fig. 1.-Corduba republicana. Re Mezquita-Catedral. 5. Alcázar de los Reyes Cristan. 4. 
algunas vías y se las dota de cloacas adinteladas construidas en sillería, según pusieron de manifiesto las excavaciones citadas. No sería extraño que se hubiera realizado alguna mejora en el foro, aunque nada seguro sabemos al respecto. La existencia de una basílica está atestiguada por las fuentes literarias, si bien la confirmación arqueológica es desgraciadamente mucho más problemática. Lo mismo vale para el templo que se supone existió en el entorno ".

Aspecto no menos significativo a tomar en consideración es la integración paulatina del río en la imagen de la ciudad. Evidentemente, control del espacio, que mediaba entre ambos, debió haber siempre, pero es ahora cuando parece que se impone la necesidad de contar con una instalación portuaria, aunque fuera modesta, para dar salida por vía fluvial a los productos agrícolas y metalúrgicos de la región. Otro indicio de que a finales de época republicana se frecuentan más los aledaños del río, es la hipótesis de C. Márquez sobre la presencia de un posible santuario extramuros por el lado SO, establecida a partir del estudio de materiales arquitectónicos posteriormente reutilizados en la muralla augustea ${ }^{12}$

La regeneración de la imagen de la ciudad no es menos clara, observada desde el ámbito privado. El incremento de actividades edilicias públicas implica mejoras cualitativas, cuya repercusión en los planteamientos de los particulares no se hizo esperar. Las aspiraciones de mayor confort y las pretensiones de habitar casas embellecidas estaban bastante generalizadas, a juzgar por el panorama entrevisto en las últimas indagaciones arqueológicas. Éstas han aportado pruebas inequívocas de cambios sustanciales en técnicas y materiales constructivos, entre los que destacan la utilización de la piedra como material básico, las decoraciones parietales estucadas y pintadas, los pavimentos de signinum, las techumbres de tegulae. La casa de atrio se documenta por vía arqueológica y literaria, pero incluso en estas fechas tempranas parece haber sido preferida la casa de peristilo, situación prolongada a lo largo de época altoimperial ${ }^{13}$. Aunque el estudio del material complementario - mobiliario, objetos decorativos - se encuentra en estado incipiente, las observaciones consignadas hablan de la superación de aquella facies modesta advertida en las casas del periodo fundacional y el acceso a un nivel mucho más evolucionado. Conviene recordar que, si los

"León, Nueva visión, cit. (n. 8), 21. Márquez, cit. (n. 7) 174.

12 Márquez, cit. (n. 7) $180 \mathrm{ss.}$

13 Carrillo, Arquitectura doméstica, cit. (n. 8) 62 ss. testimonios arqueológicos no son más explícitos en confirmarlo, es en buena medida a causa del tributo - severísimo castigo impuesto por César-que la ciudad hubo de pagar al término de las Guerras Civiles, por haber militado en el bando pompeyano. Aun así, en el estado actual de conocimientos hay razones para afirmar que a Corduba llegaba el reflejo de la luxuria privata ${ }^{14}$.

Sobre la base de matices tenues se perciben incluso los efectos de una cierta helenización ${ }^{15}$. Es el caso de la Tyche de Corduba representada en los denarios emitidos por el joven $\mathrm{Cn}$. Pompeyo en el año 46-45 a. C. Según la atractiva hipótesis de R. Volkommer ${ }^{16}$ no se trataría solamente de una de las primeras personificaciones de ciudad conocidas en Roma en cuños numismáticos, sino que existe la posibilidad de que los denarios hubieran sido acuñados en la ceca de Corduba, posibilidad que requeriría la presencia de artesanos cualificados. El alcance que éste y otros precedentes tendrían en el plano plástico e iconográfico quedará de manifiesto en la etapa inmediatamente posterior.

La inauguración del nuevo régimen político impuesto por Augusto convierte a Córdoba en colonia civium Romanorum ${ }^{17}$, cuyo cognomen Patricia basta para sugerir aspectos cruciales en su trayectoria, determinantes en su itinerario de monumentaliza-

14 En relación con la riqueza y el lujo de las casas cordobesas de esta época existe una tendencia a sobrevalorar un episodio histórico recordado por las fuentes. Se trata de la fastuosa celebración del regreso de Q. Cecilio Metelo Pío en el año 74 a. C., organizada en ciudades de la Hispania Ulterior. Aunque las fuentes no mencionan expresamente a Corduba, es lógico que en cuanto capital de la Provincia participara activamente y que en ella se celebrara la ceremonia espectacular referida por las fuentes. Evidentemente el episodio sugiere ambiente de lujo y ostentación, pero no hay que olvidar que se trata de una ocasión excepcional y posiblemente de un montaje oficial para dicha ocasión. En mi opinión, es arriesgado a partir de ahí llegar a generalizaciones sobre el lujo y la riqueza de las casas cordobesas. Lo mismo se puede decir a propósito del grupo de poetas que cantó las glorias de Metelo, poetis pingue quiddam sonantibus atque peregrinum, a decir de Cicerón (Cic., Pro Arch. 10, 26). No obstante, que Corduba contaba con círculos cultos e intelectuales lo asevera Séneca el Viejo, cordobés y buen conocedor de esos círculos; todavía a comienzos de época imperial recuerda Séneca el Viejo humorísticamente el episodio del recital en honor de Metelo (Sen., Suas. VI, 27). Una clarificación acerca de todas estas referencias literarias y de su relación con las casas cordobesas en J. Beltrán, «Luxuria helenística en la Hispania tardorrepublicana», II Reunión de historiadores del mundo griego antiguo. Homenaje a F. Gascó, Sevilla, 1997, 311 ss.

15 Ibid. 325 ss. y n. 1.

16 R. Volkommer, «Darstellungen der Personifikation von Tarragona", en: La ciudad en el mundo romano. Actas del XIV Congreso Internacional de Arqueología Clásica (1993), Tarragona, 1994, 436 ss. fig. 1.

${ }_{17}$ Stylow, cit. (n. 2) 79 ss. Ventura, León, Márquez, cit. (n. 3) $92 \mathrm{ss}$. 


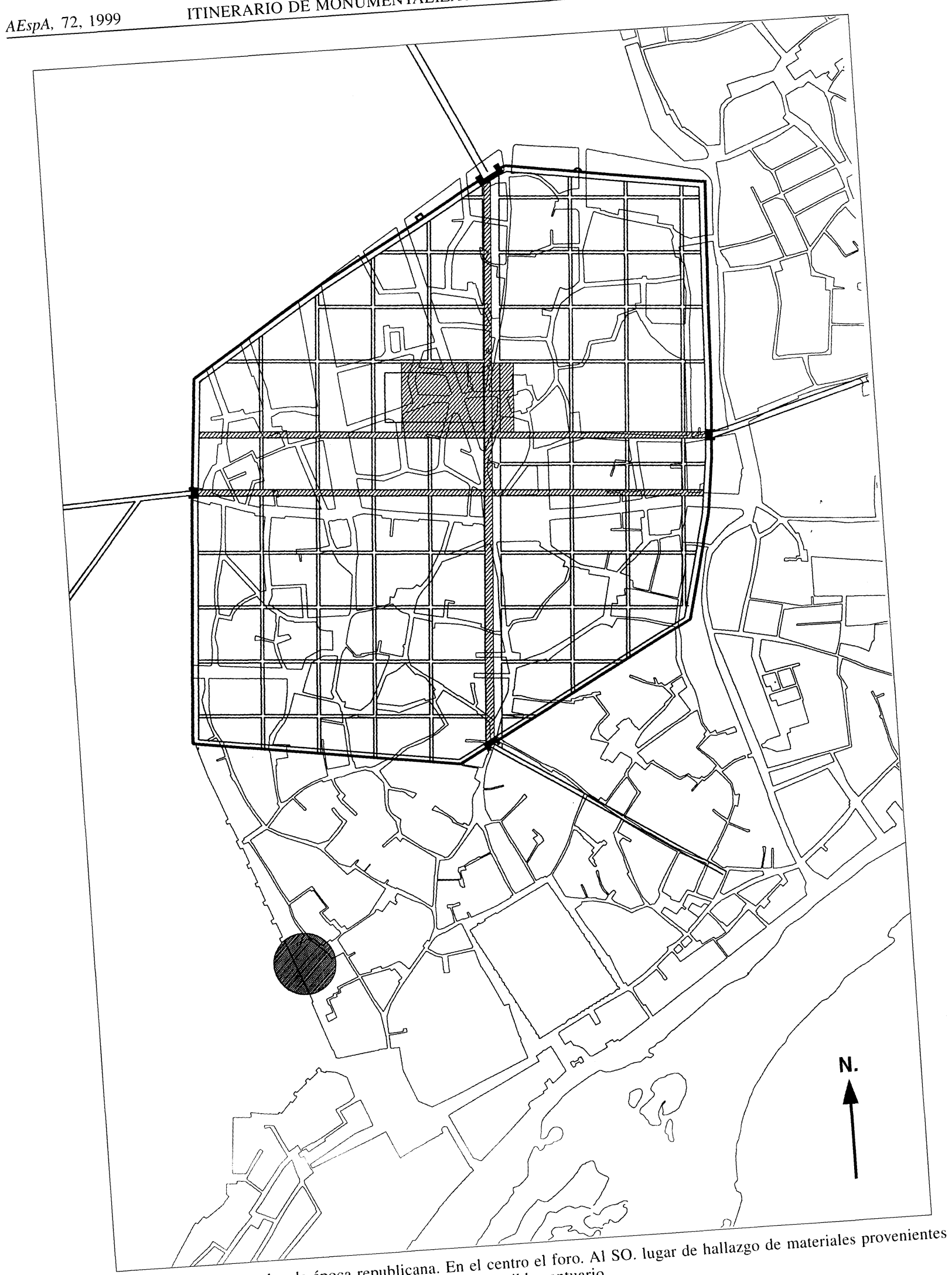

Fig. 2.-Corduba a finales de época republicana. En de un posible santuario. 
ción (fig. 3). En primer lugar, la ciudad se vincula al Senado, tutelada por los patres; en segundo lugar, ve confirmado el rango de capital de la nueva provincia Baetica, de donde su adhesión inquebrantable al Princeps. En tercer lugar, se le despierta un afán creciente por emular a Roma y por seguir su ejemplo en la línea de monumentalización. Por último, los particulares -el sector social más influyente y poderoso sobre todo- se involucran en el proceso de monumentalización y dejan constancia de ello enfáticamente. Llegados a este punto es obligado preguntarse cuál fue el orden de prioridades que rigió la reconstrucción de la ciudad. Aunque todavía queda mucho por indagar al respecto, sabemos que las exigencias de la vida cotidiana marcaron la pauta, de ahí que se consideraran prioritarias las obras de infraestructura, servicios y organización sectorial de la ciudad. Las numerosas obras de infraestructura acometidas en época augustea — pavimentación de calles, pórticos en algunas de ellas, fuentes, puente sobre el Baetis - adquieren gran trascendencia, porque revelan la faceta comunitaria de los opera publica y porque sustentan la modernización de la vetusta Corduba. Del apoyo del Princeps a esta política edilicia hay diferentes pruebas; por una parte, la munificencia imperial debió contribuir a sufragar los gastos originados por la construcción del acueducto, el aqua Augusta ${ }^{18}$; por otra, la epigrafía confirma actividades evergéticas privadas como las donaciones de fuentes públicas hechas por el duunviro L. Cornelius ${ }^{19}$. En cuanto a la organización sectorial de la ciudad, el punto de partida es la ampliación del espacio urbano hacia el sur, hasta alcanzar la orilla del Baetis. Parcelación de este espacio y modulación de la red viaria han sido determinados con bastante precisión, pues sobre el cambio de orientación se advierte que la distancia entre los cardines es de un actus, mientras que entre los decumani viene a ser de dos actus, lo que origina insulae de aproximadamente $35 \times 70 \mathrm{~m}^{20}$. La ciudad en su conjunto fue dividida en sectores o barrios, dos de los cuales vicus forensis y vicus Hispanus - son mencionados en los pedestales que los respectivos vicani dedicaron a L. Axio en época de Tiberio ${ }^{21}$. Un tercer barrio o sector, independiente y bien definido, estuvo reservado a los edificios para espectáculo, teatro y anfiteatro. Un cuarto es el portuario, peor conocido que

18 A. Ventura, El abastecimiento de agua a la Córdoba romana. II. Acueductos, ciclos de distribución y urbanismo, Córdoba, 1996, 28 ss.

${ }_{19}$ Ibid. 94 ss.

${ }^{20}$ Carrillo y otros, cit. (n. 1) 32 ss.; Ventura y otros, Análisis, cit. (n. 3) 93 ss. 105 ss.

21 $C I L I I^{2} / 7,272$ y 273 los anteriores, pero cuya existencia es indudable, porque hasta allí llegó el abastecimiento de agua ${ }^{22}$ y porque las actividades relacionadas con el comercio fluvial se incrementaron.

En el plano de las prioridades artísticas y plásticas la época augustea es una etapa decisiva para Colonia Patricia. Lo primero que se advierte es la renovación de la imagen de la ciudad, determinada ante todo por la ampliación considerable del espacio urbano. Rota la cápsula del oppidum republicano, se producen dos cambios de gran alcance. El primero de ellos está en las líneas perimetrales más abiertas que dan a la nueva colonia una apariencia más libre y distendida. El segundo es el impulso dado al antiguo eje secundario, el decumano, solución que enlaza con la planificación de una fachada monumental, capaz de proporcionar una panorámica de gran ciudad a quienes accedían a ella desde el flanco oriental por la Vía Augústea. La configuración de esta fachada requirió tiempo, esfuerzo y gasto, de ahí que se lleve a cabo en etapas sucesivas que jalonan el itinerario de monumentalización. Así el primer polo de atracción, integrado en el proyecto augusteo, se articula sobre el binomio constituido por teatro y, probablemente, anfiteatro, al igual que en Emerita Augusta. En cambio, el signo más representativo de la nueva imagen, que es el complejo monumental formado por recinto de culto imperial y circo, se retrasa hasta época claudia, como luego veremos.

En relación con las prioridades plásticas propiamente dichas, hay que destacar dos focos, desde los que irradia el nuevo mensaje ideológico. Uno es el foro, otro un espacio público dedicado al culto del Emperador. Empecemos por el foro, punto crucial en la nueva colonia. En la medida de lo que hoy sabemos, el foro fue ampliado, renovado y embellecido a partir del preexistente. Las excavaciones últimas y el análisis minucioso de la decoración arquitectónica permiten saber que era una plaza rectangular, porticada y pavimentada con grandes losas de piedra. Sin que sepamos la localización exacta, hubo en ella un templo construido todavía en piedra caliza, de cuyas proporciones dan idea las ménsulas inmensas reconocidas por C. Márquez ${ }^{23}$. El acceso a la plaza desde el cardo máximo estaba probablemente señalado por un arco, según deduce Márquez del hallazgo de una clave decorada con una victoria ${ }^{24}$. De la decoración escultórica quedan muy pocos restos, pero algunos tan representativos

\footnotetext{
22 Ventura, cit. (n. 18) 75-77, n. 155.

${ }_{23}$ Márquez, Decoración, cit. (n. 7) 174 lám. 35 abajo.

24 Ibid. 175 lám. 49.
} 


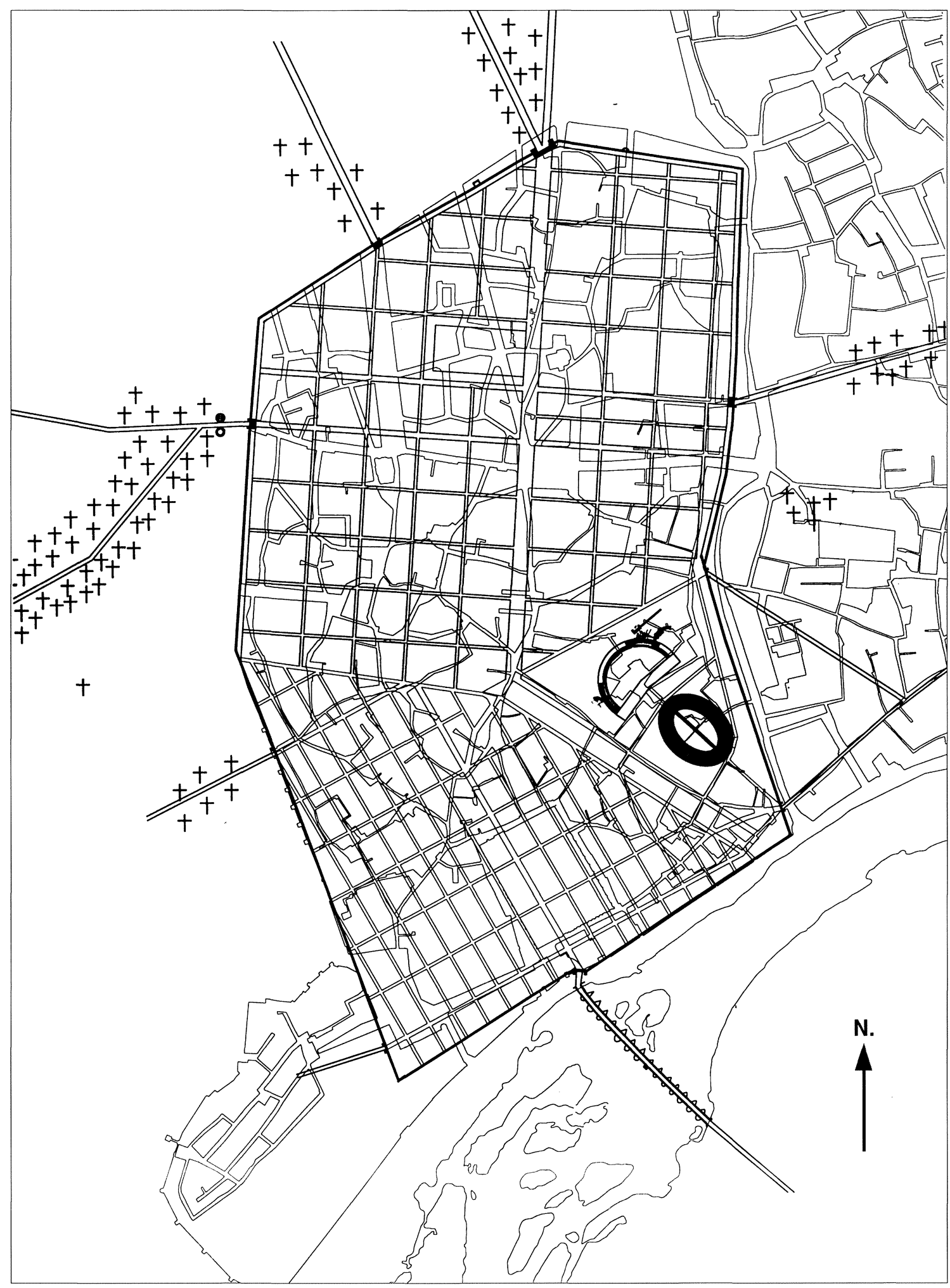

Fig. 3.-Colonia Patricia a comienzos de época imperial. Necrópolis en la periferia urbana. 
como un fragmento de placa marmórea con escena de sacrificio, conservado en el Museo Arqueológico de Córdoba, ayuda a evocar lo que debió ser en cuanto a contenido iconográfico y a estilo el conjunto ${ }^{25}$. A idéntica conclusión llevan piezas escultóricas mayores que el natural, como la parte posterior de una estatua masculina sedente, perteneciente al tipo «Jupiterkostüm», y el torso femenino de una estatua asimismo sedente, vestida con túnica finísima y manto, cuya dependencia de modelos clásicos viene determinada por el tratamiento de las formas corporales y del vestido ${ }^{26}$.

En poco tiempo a este foro se anexiona otro, en el que hace acto de presencia con todo lujo el mármol. Los estudios de Márquez han demostrado que en este forum adiectum se integraron un pórtico, un templo y un ara y que el modelo es el forum Augustum $^{27}$. Los escasos fragmentos conservados de decoración arquitectónica, minuciosamente estudiados por Márquez, sugieren para el templo una réplica del templo de Mars Ultor. Así lo dan a entender dos piezas pertenecientes a una antefija y a un capitel, equiparables en dimensiones, estilo y técnica a los del modelo augusteo; a su vez, el paralelo a escala con algunos de los aurea templa (templo de los Dioscuros y de la Concordia en el foro romano) reafirma la estrecha dependencia ${ }^{28}$. Lo mismo se puede decir del precioso fragmento de una pilastra de esquina atribuida por Márquez a un altar en la línea del Ara Pacis ${ }^{29}$. La cronología de comienzos de época julioclaudia y la adscripción a un taller romano, propuestas por Márquez, concuerdan con la única pieza del programa iconográfico identificada hasta el momento. Se trata de un torso de 1'90 m perteneciente a una estatua loricata, en la que W. Trillmich reconoce el Eneas del conocido grupo escultórico del Forum Augustum ${ }^{30}$. Aunque con dudas, a causa de la confusión en las circunstancias del hallazgo, también la galería de summi viri podría ser reconocida en la serie de once togati del Museo Arqueológico de Córdoba, según la hipótesis de I. López ${ }^{31}$. En atención al trabajo excelente del mármol y a las dimensiones mayores que el natural

\footnotetext{
25 J. A. Garriguet, «Relieve con oferente», en: D. Vaquerizo (ed.), Córdoba en tiempos de Séneca, Córdoba, 1996, 62 ss.

la hipótesis resulta plausible. El hecho de que estos mismos temas escultóricos se encuentren en el forum adiectum de Emerita Augusta ${ }^{32}$, donde además se imita el esquema decorativo de clípeos y cariátides, demuestra la cohesión respecto al modelo. Bien es verdad que tanto en Mérida como en Córdoba falta información sobre la planta, concretamente sobre elementos tan definitivos como las exedras. Sin embargo, el trabajo magistral de P. Gros sobre el forum adiectum de Arles ${ }^{33}$, induce a pensar que programas tan estrictos y afines desde un punto de vista ideológico no omitirían posiblemente un rasgo tan característico, sin olvidar que el rasgo más característico de estas imitaciones es la selección de citas tomadas del modelo, sean cuáles sean, como señala Gros ${ }^{34}$

En relación con el forum adiectum de Colonia Patricia y con la reproducción en ella del forum Augustum, o de sus elementos más representativos al menos, merece la pena recordar que el año $25 \mathrm{~d}$. C. una delegación de patricienses acudió a Roma con el fin de obtener permiso de Tiberio para erigir un templo en su honor y en el de su madre, Livia. La conocida respuesta del Emperador declinando el honor y aconsejando que tales honores se dirigieran a Divo Augusto, no puede menos que ser evocada a propósito de la actitud mimética que refleja el forum adiectum.

El segundo de los focos antes mencionados es otro espacio público, peor conocido pero no menos interesante. Sabemos que se ubica en pleno centro de la ciudad y que es una plaza pavimentada con grandes losas de piedra, como el foro. Poco más sabemos acerca de su configuración, pero el material arqueológico procedente del entorno permite avanzar en la elaboración de una hipótesis, que ya expuse hace años. Los abundantes hallazgos escultóricos, entre los que se encuentran retratos de $\mathrm{Li}$ via y Tiberio ${ }^{35}$, estatuas honoríficas acéfalas ${ }^{36}$, una esfinge de tipo egipcio ${ }^{37}$, son parte de un programa iconográfico relacionado con la propaganda oficial. La esfinge concretamente alude al triunfo de Octavio sobre Egipto, testimonio que es necesario rela-

32 J. L. de la Barrera, W. Trillmich, «Eine Wiederholung der Aeneas-Gruppe vom Forum Augustum samt ihrer Inschrift in Mérida», $R M 103,1996,119$ ss

${ }^{33}$ P. Gros, «Un programme augustéen: Le centre monumental de la colonie d'Arles», $J d I$ 102, 1978, 348 ss. 357 ss. fig. 15-18. Id., Architecture, cit. (n. 4) 231 fig. 280.

34 Ibid.

35 J. A. Garriguet, «El culto imperial», en: D. Vaquerizo (ed.), cit. (n. 25), 1996, 50 ss.

${ }^{36}$ López, Estatuas, cit. (n. 31) 68 n 37,75 ss. no $44-45$, $79 \mathrm{n}^{\circ} 48$.

37 A. M ${ }^{a}$ Vicent, «Lote de esculturas romanas de los Altos de Santa Ana», Corduba Archaeologica 15, 1984-1985, 57 ss. 
cionar con otros del culto a las divinidades tutelares, Apolo y Diana, verificados en el mismo entorno. La información extraída de una inscripción dedicada a Diana Augusta ${ }^{38}$ y de algunos elementos de la ornamentación arquitectónica, cuyos motivos evocan los de época augustea, ha llevado a C. Márquez a sugerir la presencia de un Aedes Dianae ${ }^{39}$; por su parte una pierna con una cítara adosada, de mármol blanco, hallada a escasa distancia y conservada en el Museo Arqueológico de Córdoba, pertenece evidentemente a una estatua de Apolo ${ }^{40}$. Si se conjugan todos estos datos, parece razonable considerar que este lugar fuera una especie de area sacra o atrio, tal vez un Augusteion, en el que se venerara a Augusto y a su familia. Manifestaciones tempranas del culto al Princeps son sobradamente conocidas en las provincias occidentales ${ }^{41}$ y precisamente la Bética se distinguió desde muy pronto por ellas. Recuérdese que en el año 2 a. C. le erigió una estatua de cien libras de oro en el forum Augustum, como recuerda la inscripción dedicatoria ${ }^{42}$. Nada tendría, por tanto, de extraño que la capital de la Provincia destacara en tales manifestaciones. En la capital de la Lusitania, Emerita Augusta, así como en otras ciudades de Hispania, están atestiguadas manifestaciones similares ${ }^{43}$.

De los edificios planificados en época augustea el más monumental fue el teatro. La coincidencia feliz y fortuita de su localización dentro del Museo Arqueológico de Córdoba ha facilitado la indagación arqueológica, sumamente fructífera, aunque todavía incipiente ${ }^{44}$. El edificio se asienta sobre la cota más alta de la ciudad y aprovecha la pendiente que desde allí desciende hacia el río. Para su construcción se utilizó un diseño en terrazas simétricas que circundan la cavea, articulan la circulación externa y embellecen el entorno. Las numerosas piezas de cornisas de doble frente labradas en piedra caliza grisácea, algunas cornisas molduradas con capitel toscano de pilastra, una clave de arco decorada con una máscara trágica, son elementos que

\footnotetext{
${ }^{38} C I L I I^{2} / 7, \mathrm{n}^{\circ} 222$.

39 Márquez, Decoración, cit. (n. 7) 181 ss.

${ }^{40}$ Mus. Arq. Córdoba, no inv. 1.036. A juzgar por lo conservado, pudo haber sido obra posterior, lo cual probaría la continuidad del culto a Apolo en el lugar. Lo mismo ocurre con el culto a Diana.

${ }_{41}$ P. Zanker, Augustus und die Macht der Bilder, 1987, 304 ss.

${ }^{42}$ CIL VI, 31627, Dessau I, 103

${ }^{43}$ León, Nueva visión, cit. (n. 8) 24 ss. T. Nogales, «Programas iconográficos del foro de Mérida: El templo de Diana», II Reunión sobre escultura romana en Hispania, 1996. 115 ss. 130. J. Ruiz de Arbulo, «El gimnasio de Emporion», Butlletí Arqueològic V-16, 1996, 36 ss. fig. 2.

${ }^{44}$ Ventura, León, Márquez, cit. (n. 3) 101 ss.
}

han permitido una aproximación a la fachada exterior del teatro. El desarrollo en arquería y la superposición de órdenes son rasgos que vienen sugeridos por los elementos citados y que fueron tomados de un modelo tan prestigioso como el teatro de Marcelo. La dependencia se ve confirmada por otros rasgos sobresalientes del teatro cordobés, como son la amplitud de las dimensiones, de la que da idea el diámetro de la cavea, $125 \mathrm{~m}$, y la ausencia de pórtico tras de la escena ${ }^{45}$. Augusteo también, próximo al templo de Mars Ultor, es el modelo de los capiteles de la scaenae frons ${ }^{46}$. Lo mismo se puede decir respecto al modelo de otras piezas muy deterioradas, pero muy expresivas, como son un fragmento de clípeo y dos fragmentos de un relieve con guirnalda y cisne. Motivos y procedencia de la zona alta del teatro sustentan la hipótesis, formulada con toda cautela por C. Márquez, de que estos elementos decoraran un altar o un edificio situado por encima del teatro, algo así como un sacellum in summa cavea. De ser cierta esta hipótesis, corroboraría el nexo advertido por P. Gros desde muy pronto entre teatro y culto imperial en Hispania ${ }^{47}$.

Dos cuestiones cruciales, cronología y comitente del teatro, requieren comentario. De lo hasta ahora dicho se infiere que el teatro de Colonia Patricia es básicamente obra augustea; su modelo fue el teatro de Marcelo y así lo ponen de manifiesto dos rasgos tan característicos como la utilización del «Theatermotiv», es decir, de la arcada entre órdenes aunados bajo entablamento horizontal, y de la arquivolta decorada con una máscara ${ }^{48}$. Técnica y estilo de determinados elementos de decoración arquitectónica, por una parte, y utilización de mármoles polícromos, por otra, indican que el proceso de embellecimiento y ornamentación se prolonga durante la época julioclaudia. En menor grado se constatan intervenciones en el siglo II, para instalar dos estatuasfuentes, y en el siglo IV, para alguna refectio en la escena ${ }^{49}$. En cuanto a la cuestión de quién y cómo se sufragarían los gastos de una obra tan grandiosa y costosa, parece que nos encontramos ante una situación similar a la expuesta en relación con el acueducto y las fuentes públicas, es decir, posibili-

\footnotetext{
45 Márquez, Decoración, cit. (n. 7) 182 ss. Id., «Modelos romanos en la arquitectura monumental de Colonia Patricia Corduba», $A E \operatorname{spA} 71,1998,124$ ss. A. Ventura, «Los edificios de espectáculos», en D. Vaquerizo (ed.), cit. (n. 25), 82

46 Márquez, Decoración, cit. (n. 7) 184 n. 447, 188 ss. Id., Modelos 126 n. 52, 130.

${ }^{47}$ Márquez, Decoración, cit. (n. 7) 185 ss. n. 457. Id., cit (n. 45), 127 ss. n. 62.

${ }^{48}$ Gros, Architecture, cit. (n. 4) 282 ss.

49 Márquez, Decoración, cit. (n. 7) 191 ss. Id., Modelos 132.
} 
dad de contar con munificencia imperial y activa participación de los miembros de la élite. Según una hipótesis de A. Ventura fue la familia de los Mercellones Persini, una de las más ricas entre las muchas que hubo en la Córdoba romana, la que más se distinguió en sufragar gastos. La marca M. P. repetida en las cornisas puede ser en opinión de Ventura prueba de dicha contribución o bien de la propiedad de las canteras ${ }^{50}$. Otro matiz en apoyo de la intervención de particulares puede ser la curiosa asociación de la guirnalda y el cisne en el relieve antes mencionado; por un lado, esa asociación indicaría que el encargo se hizo sobre la base de una selección de motivos del Ara Pacis; por otro, que existió contaminación de un esquema frecuentemente utilizado para decoración de urnas funerarias, como ya advirtió Márquez ${ }^{51}$. Lo interesante de esta clase de asociaciones es que denuncian un procedimiento típico, que P. Zanker ha observado y atribuido a los gustos y preferencias mostrados por comitentes privados ${ }^{52}$. En otro orden de cosas la documentación epigráfica relacionada con el teatro de Córdoba ha proporcionado información suplementaria tan curiosa como la anchura del asiento que tenía reservado una dama de la gens Annaea y la actividad de un acomodador ${ }^{53}$.

A Ventura se debe igualmente la propuesta de localización del anfiteatro en eje transversal con el teatro y en posición antagónica respecto a él. Aunque pendiente de constatación arqueológica, la propuesta es metodológicamente convincente, como demuestran los numerosos paralelos de fosilización en el parcelario y la disposición similar de teatro y anfiteatro en otras colonias augusteas, como por ejemplo Aosta ${ }^{54}$.

En relación con la imagen de la ciudad la clara definición del barrio de espectáculos permite extraer dos conclusiones. La primera es la configuración de sector independiente en respuesta a la idea de orden y control típica del esquema organizativo de colonias augusteas, sobre todo para ambientes y grupos tumultuosos ${ }^{55}$. La segunda es el efecto visual impresionante que causarían por proximidad y asociación dos edificios tan monumentales, por medio de

${ }^{50}$ Cf. Carrillo y otros, cit. (n. 1) 35 ss.

51 Cf. n. 47

52 Zanker, cit. (n. 41) 309 ss. Cf. Márquez, Decoración, cit. (n. 7), 188. Id., Modelos 129.

53 A. Ventura, «La documentación epigráfica», en D. Vaquerizo (ed.), cit. (n. 25) 92 ss.

${ }_{54}$ Id., «Los edificios de espectáculos», cit. (n. 25) 82 ss. Id., Abastecimiento de agua, cit. (n. 18) 171 ss. fig. 127-128.

${ }_{55} \mathrm{P}$. Zanker, «Veränderungen im öffentlichen Raum der italischen Städte der Kaiserzeit», L'Italie d'Auguste à Dioclétien, Roma, 1994, 261. los que la ciudad proclama no solamente su adhesión a la política de publica magnificentia sino también la superioridad de su rango político-administrativo y de su potencial económico.

Como advierte P. Gros a propósito de Arles ${ }^{56}$, el compromiso de continuidad con el proyecto augusteo se hace patente en época de Tiberio y el desarrollo de los programas ornamentales en el forum adiectum y en el teatro de Córdoba lo corrobora plenamente. Es más, todavía se impulsará en época de Claudio, cuando se emprende un proyecto urbanístico grandioso, con el que culmina la monumentalización de la fachada oriental de la ciudad. La intensificación de las excavaciones en esta zona durante los últimos años ha dejado de manifiesto que el nuevo complejo constaba de dos sectores claramente diferenciados; uno superior, cerrado y sacro estaba presidido por un templo, al que rodeaba un pórtico triple y antecedía un altar ${ }^{57}$; otro inferior, extenso y profano era un edificio de espectáculo, un circo. Ambos se disponían sobre un eje longitudinal y se articulaban por escaleras, tal vez por una plataforma escalonada, con la que se salvaba el fuerte desnivel del terreno ${ }^{58}$ (fig. 4).

El elemento formal que mejor permite enjuiciar el apego a los patrones oficiales y el carácter clásico de la obra es el templo, gráficamente definido por P. Gros como «un émule de la Maison Carrée» ${ }^{59}$. La cimentación, fechada en época claudia, se realizó en opus quadratum ${ }^{60}$. La misma cronología se atribuye hoy a la decoración arquitectónica, si bien los prototipos, por ejemplo de los capiteles, remiten a época augustea, más exactamente al templo de Mars Ultor ${ }^{61}$. El taller responsabilizado de estos trabajos es un buen taller local, que conoce e interpreta correctamente el lenguaje específico desarrollado en época julioclaudia ${ }^{62}$. Una prueba más del nivel cualitativo alcanzado en él es la que ofrece una pieza atribuida al friso del templo, en la que curiosamente se aprecia un procedimiento técnico a base de «puentecillos» muy similar al que por la misma época se documenta en el ciclo estatuario del

56 Gros, Programme, cit. (n. 3) 361 ss.

57 Ventura, León, Márquez, cit. (n. 3) 96.

${ }^{58}$ Carrillo y otros, cit. (n. 1) 40 ss. fig. 5

59 Ibid. 155 fig. 175.

60 J. L. Jiménez, «El templo romano de la calle Claudio Marcelo en Córdoba: aspectos cronológicos, urbanísticos y funcionales», en: P. León (ed.), cit. (n. 2) 141 ss.

${ }_{61} \mathrm{H}$. von Hesberg, «La decorazione architettonica di Cordova. Sulla funzione dell'ornamentazione architettonica in una città romana», en: P. León (ed.), cit. (n. 2) 157 ss. 167 ss. C. Márquez, Capiteles romanos de Corduba Colonia Patri cia, Córdoba, 1993, 113 ss. n 213-215.

${ }^{62}$ Ibid. 


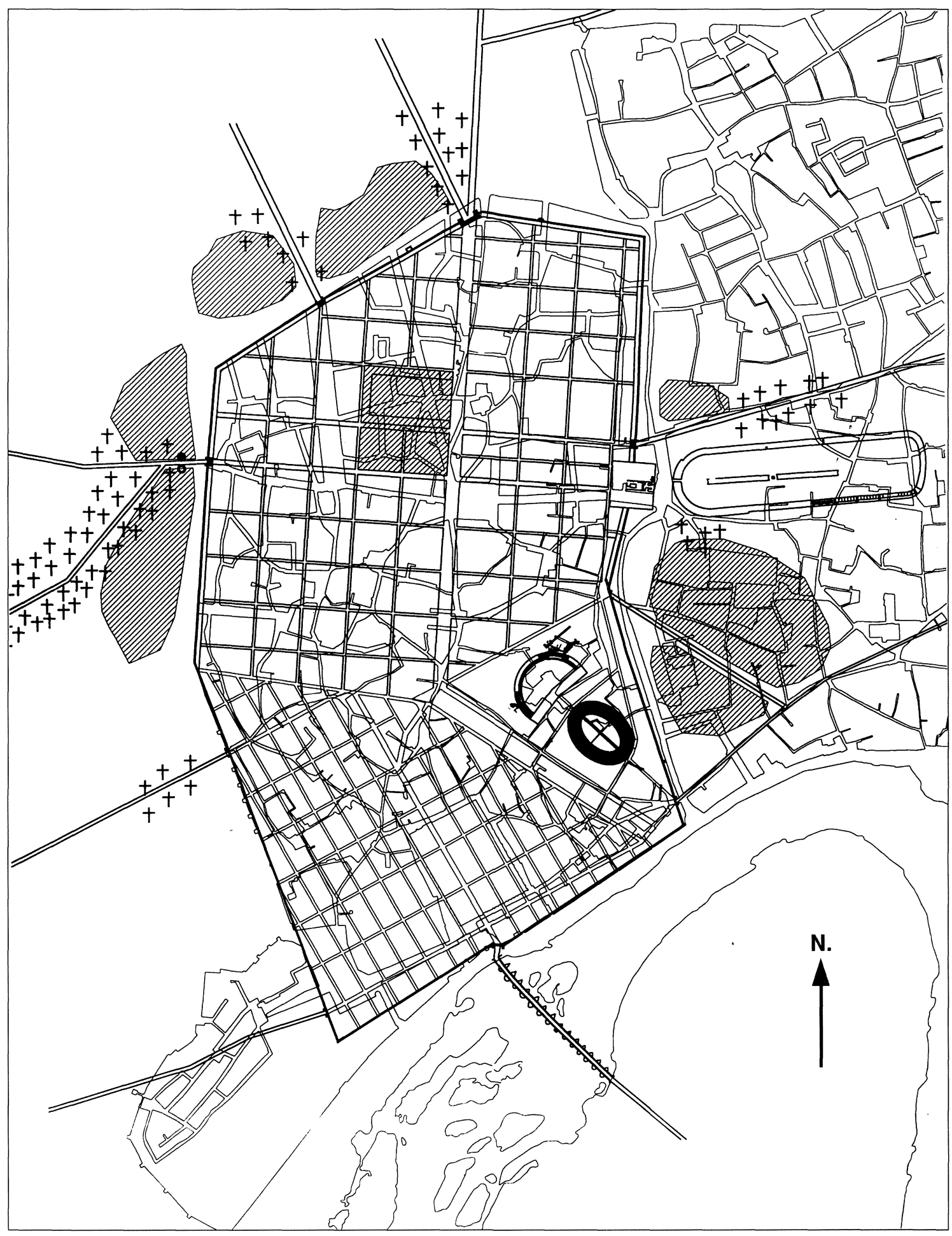

Fig. 4.-Colonia Patricia a finales de época julioclaudia. Recinto de culto imperial y circo sobre la fachada E. Nuevos vici y necrópolis en la periferia urbana. 
forum adiectum de Mérida ${ }^{63}$. El mal estado de conservación de las escasas piezas de decoración escultórica halladas en el recinto cordobés impide desgraciadamente ir más lejos en el tema de las relaciones entre talleres.

El pórtico que rodeaba el templo sólo se ha podido documentar a nivel de fundamentos; era un pórtico triple abierto a una plaza de $80 \times 60 \mathrm{~m}$, en medio de la que se alzaban templo y ara. La extensa terraza exigió una labor ingente para contener la presión y el empuje del terreno, por lo que se utilizó un potente sistema de anterides ${ }^{64}$.

En cuanto al circo, las excavaciones en curso han sacado a la luz hasta el momento una cimentación solidísima en opus quadratum, coetánea de la del templo. Dato seguro parece ser también la perduración de los trabajos de construcción hasta finales de época julioclaudia o comienzos de época flavia ${ }^{65}$.

Nos encontramos, pues, ante un típico santuario dinástico, cuyo punto de referencia inmediato es naturalmente el complejo augusteo del Palatino ${ }^{66}$. La ubicación fuera del recinto amurallado y la posición longitudinal del circo son divergencias explicables a causa de la necesidad imperiosa de un espacio suficientemente destacado y amplio, del que la ciudad ya no disponía intra moenia, y a causa de los condicionamientos topográficos del lugar elegido. Si bien la discrepancia respecto a la armonía, que se observa en el entorno del esquema original, es innegable, también lo es que el objetivo prioritario de los provinciales era dar énfasis al mensaje propagandístico de la casa imperial; y ese objetivo se veía plenamente cumplido en un complejo monumental que, convertido en fachada y punta de lanza de la capital provincial, resultaba más que emblemático. Su función debió ser la de foro provincial ${ }^{67}$, del que es un claro ejemplo, y precisamente por su organización peculiar viene a resaltar más «la rhétorique tant architecturale que liturgique» atribuida por $\mathrm{P}$. Gros a estos vastos recintos de culto imperial ${ }^{68}$. La

${ }^{63}$ W. Trillmich, «Hispanien und Rom aus der Sicht Roms und Hispaniens», en: W. Trillmich y otros (eds.), Hispania Antiqua. Denkmäler der Römerzeit, Mainz, 1993, 50 ss.

64 Jiménez, cit. (n. 60) 130.

${ }_{65}$ Agradezco a J. F. Murillo, director de las excavaciones, la información sobre los resultados obtenidos.

${ }^{66}$ La importancia que éste adquiere como modelo en las provincias occidentales y concretamente en Hispania ha sido subrayada por P. Gros, pues efectivamente todavía se reproduce a finales de época flavia en Tarraco (Tarragona), la capital de la Tarraconense. P. Gros, «Le palais hellénistique et l'architecture augustéenne: L'exemple du complexe du Palatin», en: W. Hoepfner, G. Brands (eds.), Basileia. Die Paläste der hellenistischen Könige, Mainz, 1996, 236 ss. Id., Architecture, cit. (n. 4) 229 ss. fig. 278

${ }^{67}$ Carrillo y otros, cit. (n. 1) 40.

${ }_{68}$ Gros, Architecture, cit. (n. 4) 229. perspectiva en profundidad creada por la posición longitudinal del circo no solamente ofrecería una visión majestuosa al que se acercaba a la ciudad, sino que evocaría la idea de pompa procesional inherente a la función específica del recinto de culto.

En el origen de un proyecto tan grandioso, cuya carga ideológica va tan estrechamente ligada a la casa imperial, es lógico que estén los móviles e intereses políticos de rigor. Pero en el caso de Córdoba debió contar además la situación ascendente de los provinciales en Roma y en el Senado durante los principados de Claudio y Nerón, siendo la familia de los Séneca, la gens Annaea, el paradigma por excelencia. El clima de confianza que se generaría en la ciudad pudo ser un factor influyente a la hora de tomar decisiones y afrontar gastos, fenómeno que con el tiempo se repetiría en Italica a mayor escala. Con mayor certeza se puede afirmar que un impacto comparable al provocado por este complejo de culto dinástico en la imagen de la ciudad no vuelve a producirse hasta que pasados dos siglos se construya el palatium Maximiani. Nada equiparable habrá hasta entonces, por más que la ciudad continúe avanzando en su itinerario de monumentalización.

Un parámetro imprescindible, a la hora de determinar el nivel de monumentalidad de una ciudad como Colonia Patricia, es la arquitectura funeraria. En espera de que se le dedique una investigación rigurosa y sistemática, la valoración de las manifestaciones conocidas hasta ahora arroja un balance favorable a la idea de monumentalidad. Por una parte, los restos de decoración arquitectónica esbozan un cuadro muy similar al que se encuentra en ciudades privilegiadas del Occidente romano, tanto en lo que se refiere a tipología de monumentos como a morfología de elementos ornamentales ${ }^{69}$. Por otra parte, las estructuras arquitectónicas conservadas atestiguan la existencia de necrópolis y vías funerarias en la línea del modelo romano e itálico ${ }^{70}$. Sirvan de muestra los dos mausoleos circulares recientemente excavados en la necrópolis occidental, situados a ambos lados de la vía ad Hispalim (Sevi1la), ante una puerta de la ciudad. El mejor conservado de los dos muestra a nivel del basamento una estructura cilíndrica de 13,25 m de diámetro construida en opus caementicium y revestida de sillares de piedra; una cornisa de mármol blanco coronada de almenas, de la que se conservan algunas piezas, servía como remate. En el interior una cámara circular de 3,60 m de diámetro conservaba el bus-

\footnotetext{
69 Márquez, Decoración, cit. (n. 7) 194 ss.

70 D. Vaquerizo, «El mundo funerario», en: D. Vaquerizo (ed.), cit. (n. 25) $176 \mathrm{ss}$
} 
tum y una gran cista de piedra ${ }^{71}$. La molduración de las basas del podium y la de las cornisas fijan la cronología a comienzos de época julioclaudia sobre la base del paralelo con la serie de basas de Glanum ${ }^{72}$; cronología confirmada por otros elementos del registro arqueológico. Como dato de interés hay que añadir la amortización bajo el mausoleo de un enterramiento circular tardorrepublicano con ustrinum y espacio para las urnas ${ }^{73}$.

Una cronología afín, dentro del siglo I, ha sido atribuida a dos hipogeos monumentales localizados en las necrópolis $\mathrm{N}$ y $\mathrm{O}$ de la ciudad. En ambos la técnica constructiva es opus caementicium revestido de opus quadratum y en ambos vienen a coincidir también las dimensiones de unos $4 \mathrm{~m}$ de lado. En el estado actual de conservación es muy difícil conocer el desarrollo del coronamiento, sin lugar a dudas monumental y posiblemente en forma de torre, de acuerdo con el tipo conocido de finales de la República y comienzos del Imperio ${ }^{74}$. En ningún caso nos ha llegado información epigráfica, pero la misma tipología de estos monumentos funerarios hace pensar que los comitentes pertenecerían a un nivel social distinguido, posiblemente miembros de la élite local ${ }^{75}$.

La apertura del viejo pomerium tuvo consecuencias inmediatas. Nuevos vici y necrópolis surgen a manera de cinturón periférico y hacen suponer una mayor densidad de población ${ }^{76}$. La casa de peristilo sigue siendo el tipo más frecuente y, aunque los contextos domésticos están pendientes de un análisis en profundidad, pavimentos de mosaico y elementos decorativos diversos - restos de pintura, fuentes, hermas, etc. - son indicio del nivel existente en las casas de los siglos I y II ${ }^{77}$. Más todavía lo es el incremento del consumo de agua facilitado por un segundo acueducto, el aqua Nova Domitiana Augusta. En contraste con el aqua Vetus o aqua Augus$t a$, el acueducto domicianeo era obra de envergadura, que contribuía a magnificar la imagen de la ciudad por la fachada del Norte y de Levante ${ }^{78}$. El incremento del caudal de agua, a su vez, favorece la proliferación de fuentes convertidas en referente plástico de una escenografía urbana más sofistica-

71 J. F. Murillo, J. R. Carrillo, «Monumento funerario romano de la Puerta de Gallegos», en: D. Vaquerizo (ed.), cit. (n. 25) $186 \mathrm{ss.}$

72 Márquez, Decoración, ict. (n. 7) 194 ss.

73 Murillo, Carrillo, cit. (n. 71) 186

74 Vaquerizo, cit. (n. 70) 190 ss. 194 ss

${ }^{5}$ Márquez, Decoración, cit. (n. 7) 197.

${ }^{76}$ Carrillo y otros, cit. (n. 1) 41.

77 Carrillo, Arquitectura doméstica, cit. (n. 8) 64 ss. fig. 4

78 Ventura, Abastecimiento de agua, cit. (n. 18) 27, 40 ss Ventura, León, Márquez, cit. (n. 3) 97. da ${ }^{79}$. La localización de una gran fuente circular cubierta a manera de una tholos en las inmediaciones del foro provincial suscita la sospecha de relación o proximidad del macellum ${ }^{80}$.

Toda esta zona recibe especial atención y experimenta cambios en el siglo II (fig. 5). El conocimiento que tenemos de ellos proviene de excavaciones puntuales y, en consecuencia, ofrece información parcial; pero la abundante información epigráfica ha sido una ayuda inestimable para definir la situación. Lo más interesante que hay en ella es la conversión o adaptación del area sacra o recinto de culto imperial de comienzos del Imperio a la función de foro provincial. Para finales del siglo II está consumado el cambio, pues así lo atestiguan los numerosos pedestales dedicados a flamines provinciales allí localizados ${ }^{81}$. El grandioso complejo de culto dinástico erigido a finales de época julioclaudia queda privado de su función, sin que por el momento conozcamos las causas; pero que es así lo confirma la construcción de un nuevo circo en el extremo opuesto de la ciudad, a Occidente, cuya infraestructura ha sido vista en parte ${ }^{82}$. De la preponderancia de este nuevo circo da idea el hecho de que se construya un tercer acueducto, para abastecerlo suficientemente de agua ${ }^{83}$. En relación con el desplazamiento de la dinámica urbana, en buena parte, a la zona occidental de la ciudad hemos de valorar el hecho cierto de que las exigencias de la vida cotidiana basculan en busca de nuevos intereses y posibilidades. Eso es lo que da a entender, por una parte, la saturación de obras públicas, ciclos estatuarios y demás referentes monumentales en los espacios representativos conocidos; por otra, la modernización y mejoría progresiva que desde época julioclaudia experimentan antiguas zonas marginales, como es el caso del vicus occidental.

Aunque todavía para los siglos II-III se documentan por hallazgos epigráficos obras de importancia, como los posibles templos de Tutela y de la Magna Mater ${ }^{84}$, la realidad está protagonizada por la atrofia de los focos emblemáticos, a excepción del foro colonial. Por primera vez la imagen de Colonia $\mathrm{Pa}-$ tricia se contrae y ofrece síntomas inequívocos de crisis y transformación. Además de los aludidos, merece especial mención por significativo el decaimiento del interés por la autorrepresentación, que se

${ }^{79}$ Ventura, Abastecimiento de agua, cit. (n. 18) 106 ss. fig. 73-74.

${ }_{80}$ Ibid. 99 ss. fig. 64-69. Id., «Fuente circular», en: D Vaquerizo (ed.), cit. (n. 25) 128.

81 Ventura, León, Márquez, cit. (n. 3) 96.

82 Carrillo y otros, cit. (n. 1) 39 ss. 43 ss

83 Ventura, Abastecimiento de agua, cit. (n. 18) 185 ss.

${ }^{84}$ Carrillo y otros, cit. (n. 1) 37, 39. 


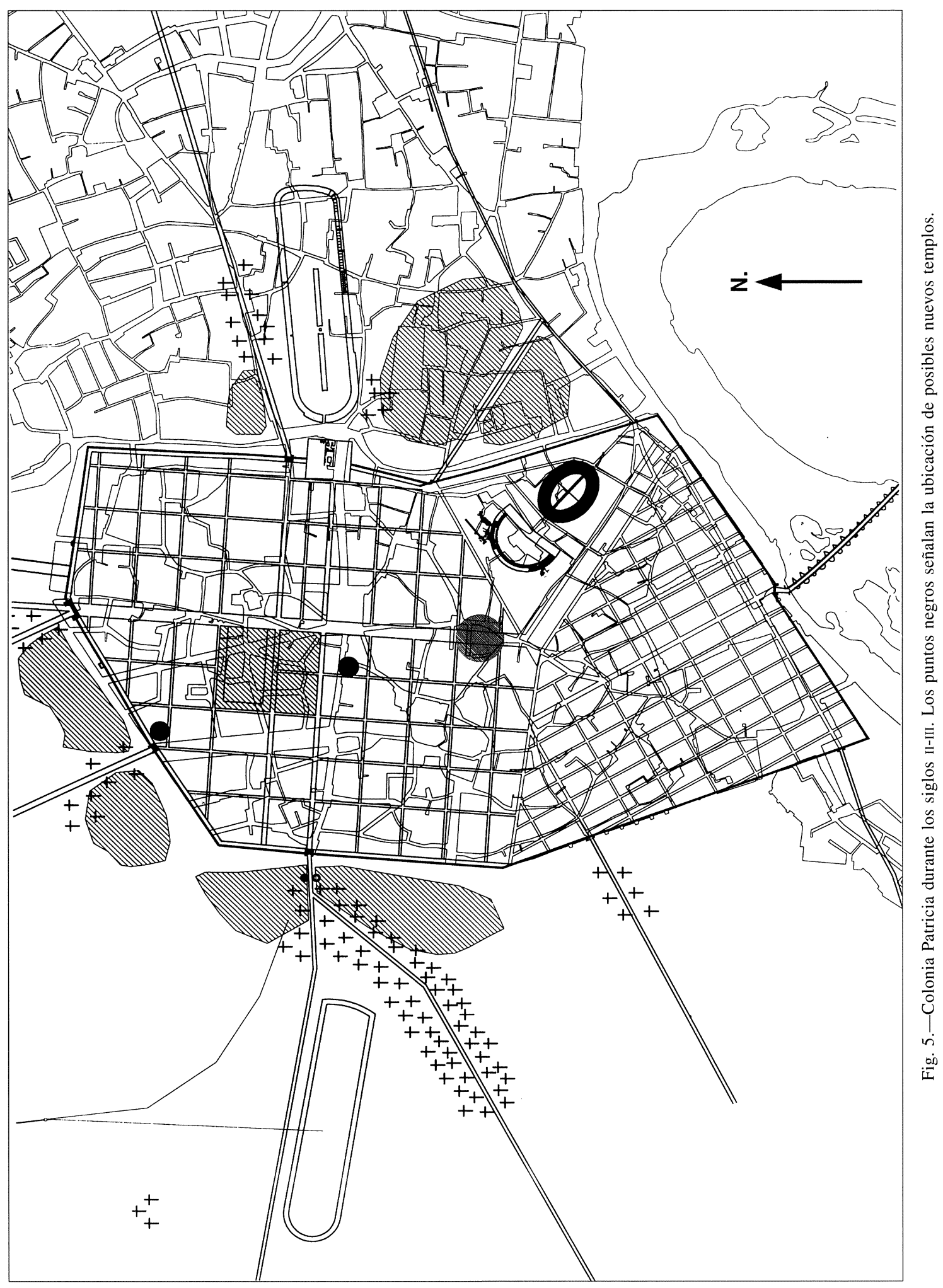




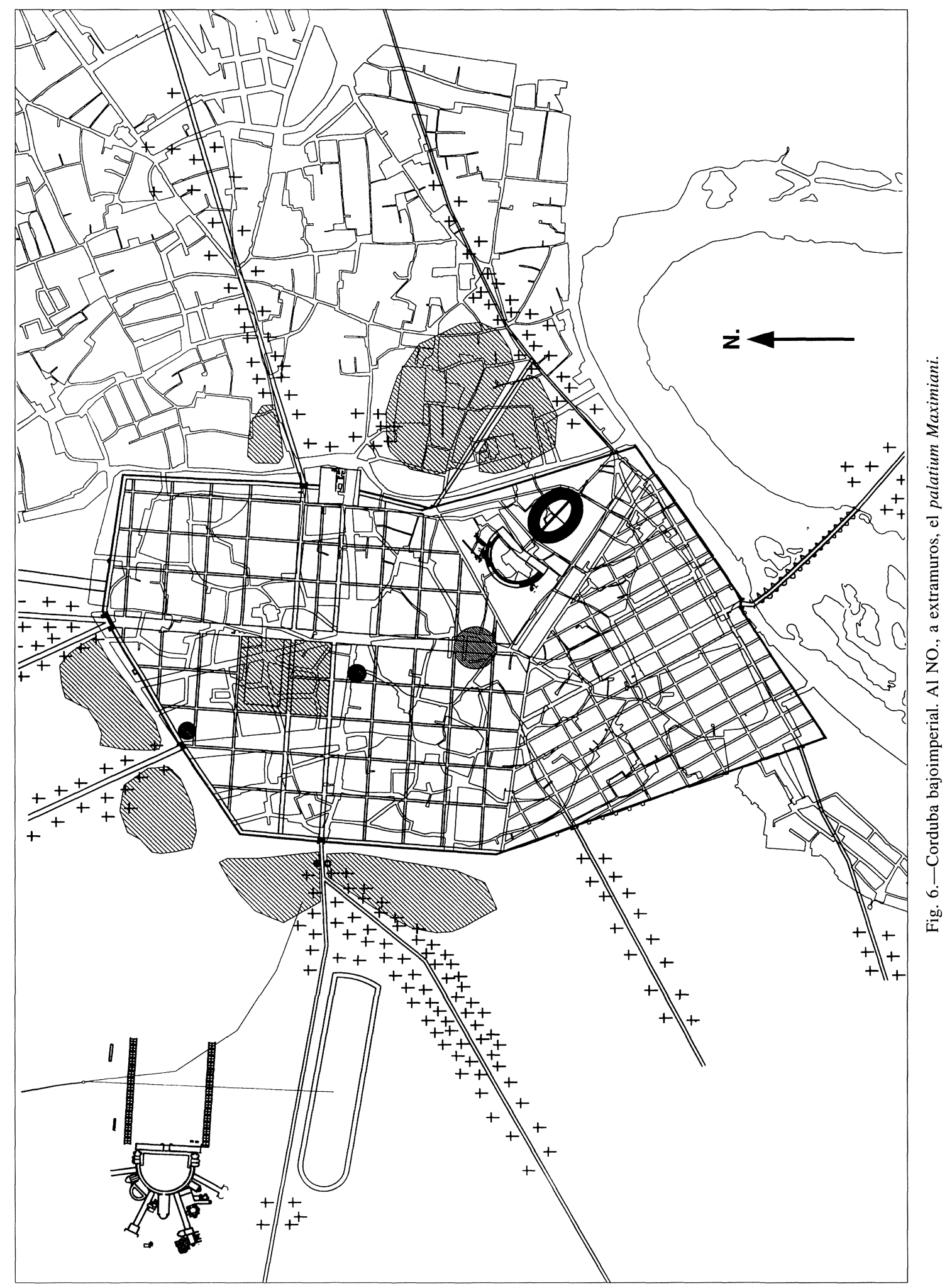


traduce en un descenso considerable en la producción de estatuas honoríficas y retratos, especialmente en mármol.

Cuando la prosperidad parece desvanecerse y la ciudad se refugia en su viejo nombre, Corduba, llega el impulso del más espectacular de los proyectos acometidos en ella, el palatium Maximiani, un nuevo revulsivo para su imagen. El trabajo modélico, por riguroso y brillante, que R. Hidalgo ha realizado en él tanto durante las fases de trabajo de campo como durante las de análisis e interpretación del monumento, aporta una información rigurosa y exhaustiva. Su importancia no sólo ha de medirse por la repercusión directa sobre un yacimiento arqueológico excepcional, sino por la renovación que ha supuesto en la investigación sobre la arquitectura de representación en época bajoimperial y, por supuesto, sobre la Córdoba tardorromana ${ }^{85}$. Aspectos fundamentales de las tesis establecidas por Hidalgo son los siguientes:

El complejo palatino se erige fuera de la mura1la, en el sector NO de la ciudad, por la necesidad manifiesta de disponer de espacio y terreno apto para una construcción de magnitud extraordinaria, más de $400 \mathrm{~m}$ de longitud y $200 \mathrm{~m}$ de anchura; el edificio ocupaba, por tanto, $8 \mathrm{Ha}$. La elección del lugar estuvo condicionada, además, por la existencia previa de un circo a escasa distancia, que quedó incorporado al magno complejo palatino, probablemente renovado y embellecido ${ }^{86}$. Desde el siglo I d. C. el lugar había estado ocupado por una villa suburbana que fue arrasada con motivo de la nueva edificación ${ }^{87}$.

La definición proyectual combina la inmensidad volumétrica y la originalidad del diseño. Su objetivo es reflejar la nueva imagen del poder central, cuya simbología se plasma en la disposición radial de los elementos compositivos respecto a la inmensa exedra semicircular central. En este sentido es interesante observar el cambio de esquema producido en la arquitectura de representación respecto a época altoimperial; por una parte, se adopta una forma más abierta, pero claramente jerarquizada; por otra, se facilita el análisis visual de una escenografía grandiosa, sobre la que se proyecta claramente la idea de poder. El resultado final propiciado por la curva es generar un ritmo y una pauta acordes con

${ }^{85}$ R. Hidalgo, Espacio público y espacio privado en el conjunto palatino de Cercadilla (Córdoba): el aula central y las termas, Sevilla, 1996. Id. y otros, El criptopórtico de Cercadilla. Análisis arquitectónico y secuencia estratigráfica, Sevilla, 1996.

86 Hidalgo, Espacio, cit. (n. 85) 17 ss., 150.

87 R. Hidalgo, M. Moreno, «La villa suburbana de Cercadilla», en: D. Vaquerizo (ed.), cit. (n. 25) 122. una visión mayestática del poder, típica de la época. Este aspecto de la cuestión es decisivo para comprender que el arquitecto es alguien proveniente del círculo imperial, conocedor de los principios y directrices que rigen la llamada «architettura di potenza» ${ }^{88}$

El análisis comparativo de grandes edificios en exedra a lo largo de la arquitectura romana ha permitido a Hidalgo valorar la aportación renovadora que supone el diseño de este complejo palacial ${ }^{89}$, pleno de sabiduría vanguardista, por así decirlo. Nótese cómo la estructura y la organización del espacio dependen del criptopórtico en sigma, en exedra; el desarrollo axial de la planta, la disposición simétrica de los elementos compositivos y el acceso fortificado son los rasgos más destacados. Aunque sea brevemente hay que comentar que el criptopórtico es el elemento vertebrador de las diferentes unidades compositivas, como lo define Hidalgo, así como también es el elemento distribuidor de la circulación interna ${ }^{90}$. Mención especial merece la diversidad de ambientes nobles, esto es, de recepción y representación - triclinia, termas, aulas - siempre espaciosos y con cabeceras absidadas. Entre las que Hidalgo designa grandes salas de recepción o audiencia sobresale a todas luces la gran aula central, situada en la cabecera del eje y dotada de termas adyacentes. La relación con la gran sala de audiencias de época tetrárquica es evidente y el paralelo más próximo es el aula palatina de Trier. Ahora bien, la consecuencia más importante de dicha relación es la prioridad cronológica del aula cordobesa, firmemente demostrada por Hidalgo; a partir de ella se ha de modificar la idea de modelo, favorable a Trier, existente hasta ahora en la arquitectura tetrárquica y volver la vista al aula de Córdoba, cuando se considere el origen de este tipo arquitectónico ${ }^{91}$. La relación directa del complejo termal con el aula central está probada por el contacto entre los respectivos muros.

La técnica constructiva es muy homogénea en todo el conjunto y resulta decisiva para fecharlo ${ }^{92}$. El material básico es el opus caementicium revestido de opus vittatum mixtum, gran novedad en la edilicia cordobesa, que utilizó siempre de preferencia el opus quadratum. Como es de suponer, según los ambientes se ha documentado también el opus testaceum, así como tesselatum y signinum para

\footnotetext{
88 Hidalgo, Espacio, cit. (n. 85) 42.

89 Hidalgo, Espacio, cit. (n. 85) 57 ss. fïg. 16

Hidalgo, Espacio, cit. (n. 85) 31 ss. 51 ss. Id. y otros, Criptopórtico 11 ss. 43 ss.

${ }^{91}$ Hidalgo, Espacio, cit. (n. 85) 63 ss. 142, 151 fig. 18

92 Ibid. 59 ss
} 
pavimentos. A este respecto hay que decir, por increíble que parezca, que en un complejo constructivo de tales dimensiones apenas se han localizado pavimentos y restos de decoración arquitectónica en materiales nobles, claro indicio de un saqueo fechado hacia el siglo $\mathrm{VI}^{93}$. En este sentido es inevitable pensar que la construcción en época califal de la vecina residencia palaciega de Medina Azahra es un factor más a tomar en consideración, entre los que contribuyeron al expolio del palatium bajoimperial.

Comitente, ocasión del encargo y cronología son cuestiones estrechamente ligadas entre sí, resueltas por Hidalgo, en parte, a partir de las conclusiones extraídas del análisis precedente $y$, en parte, con la ayuda de la muy escasa información epigráfica y con el análisis de las circunstancias históricas. Datos epigráficos hay de dos clases, unas pocas litterae aureae y un fragmento de placa marmórea. Las primeras, sólo tres completas, aparecieron en el criptopórtico formando parte de un depósito de restos metálicos, esto es, como acción del saqueo. Son de bronce dorado, miden $19 \mathrm{~cm}$ de alto y $7 \mathrm{~cm}$ de grosor y en opinión de Hidalgo pertenecieron posiblemente a la inscripción fundacional ${ }^{94}$. El fragmento de placa marmórea apareció en el frigidarium de las termas adyacentes al aula central. Pese al mal estado de conservación, el dato paleográfico apunta con seguridad a finales del siglo III-primera mitad del IV. El intento de restitución del texto, hecho con sumo rigor, es plausible y alude a los césares Constancio Cloro y Galerio ${ }^{95}$. Curiosamente ambos son citados sólo por los cognomina, forma abreviada que es usual cuando se menciona a los cuatro tetrarcas, por lo que hay que suponer los nombres de los augustos, Diocleciano y Maximiano, en el comienzo del texto. La suma de estos factores lleva a situar el epígrafe entre los años 293-304 ${ }^{96}$.

Si se considera la situación de Hispania por estos años, a comienzos de la Tetrarquía, se ha de valorar la vinculación junto con Italia y el N. de África a Maximiano Hercúleo. Como es sabido, entre 296-297 Maximiano se encuentra en Hispania con el fin de preparar la campaña del N. de África y lo hace desde la capital de la Bética. Para Hidalgo éste es el motivo determinante de la construcción del $p a$ latium, reducido a sede temporal tras la solución del conflicto y tras el nuevo derrotero de los aconteci-

\footnotetext{
93 Ibid. 36, 128 ss.

94 Ibid. 36. Id. y otros, Criptopórtico 52 n. 54 fig. 55

${ }_{5}$ M. Flavius Valerius Constantius y C. Galerius Valerius Maximianus.

${ }_{96}$ Hidalgo, Espacio, cit. (n. 85) 143ss. lám. 49-51 fig. 73.
}

mientos. Al magno complejo se le asignaría entonces nueva función pero muy similar, pues pudo albergar al vicarius Hispaniarum, sin olvidar que inmediatamente después se hace presente en Córdoba Osio, el personaje más influyente del círculo de Constantino ${ }^{97}$.

La fase final del palatium Maximiani fue el abandono, sucesivas reocupaciones y la conversión de un sector del criptopórtico en basílica cristiana con una necrópolis asociada. La remodelación urbanística de época califal, en el siglo x, impone la reconversión en un extenso arrabal ${ }^{98}$.

En relación con la imagen de la ciudad tiene interés señalar que el planteamiento de una obra tan magna e innovadora como el palatium tetrárquico no rompe con las directrices configuradoras de la imagen urbana, sino que las respeta. Prueba de ello es el mantenimiento de la orientación y disposición observadas en los grandes complejos urbanísticos precedentes, sobre todo, en el de culto dinástico de finales de época julioclaudia. Al igual que éste la construcción del palatium potencia la dialéctica ciudad/campo y manifiesta la pugna de aquélla por reafirmarse y expandirse fuera de sus propios límites. Igual que ocurriera a finales del siglo I, el nuevo centro representativo de la vida oficial imanta a la privada, de donde las muestras de actividad constructiva en el sector. Por último la aportación a la magnificencia de la imagen de la ciudad es tan evidente, que no necesita comentario.

Este último destello de esplendor no pudo, sin embargo, detener el proceso imparable de cambios y transformaciones, que desde finales del siglo III y durante los siglos IV-V afectan tanto a la esfera pública como a la privada. Se trata de un fenómeno detectado a distintos niveles en las diferentes regiones del Imperio ${ }^{99}$, cuyas consecuencias fueron sumamente graves en Hispania. Rasgo típico es el abandono y la reutilización con fines privados de espacios públicos, así como el saqueo de materiales extraídos de aquéllos ${ }^{100}$. Para ilustrar la situación en Corduba, basta un ejemplo: en el siglo IV el espacio existente entre el templo y el pórtico del complejo dinástico julioclaudio es ocupado por una casa de peristilo, en cuya construcción se aprovecharon materiales saqueados de aquél ${ }^{101}$. Bien es verdad que en contraste con esta situación magníficos pavimentos de mosaico aluden al ambiente pro-

\footnotetext{
97 Ibid. 151 ss.

98 Hidalgo y otros, Criptopórtico, cit. ( n. 85) 47 ss.

2) Zanker, Veränderungen, cit. (n. 85) $266 \mathrm{ss}$

(1) Carrillo y otros, cit. (n. 1) 42 ss. Ventura, León, Márquez, cit. (n. 3) 98 ss.

101 Carrillo, Arquitectura doméstica 66, cit. (n. 8) fig. 5.
} 
pio de las ricas domus bajoimperiales ${ }^{102}$; pero es la otra cara de la moneda la que representa la tónica generalizada.

La admisión de esta realidad no debe obstruir el descubrimiento de otras perspectivas. Al igual que ocurre cuando se profundiza en otras facetas de la Antigüedad tardía, la imagen que ofrece Córdoba durante esa época tiende a ser entendida como imagen de decadencia, como término de su itinerario de monumentalización, lo cual en parte es cierto. Pero esa realidad tiene otra vertiente que no debe quedar

102 Ibid. postergada, pues muestra que las posibilidades de proseguir una trayectoria de ciudad monumental no se agotaron entonces. Las que se agotaron fueron las posibilidades de expresarla a escala clásica, esto es, de manera acorde con los esquemas propios de la Antigüedad Clásica. Tanto en la etapa visigoda como bajo la dominación islámica la ciudad se incorpora a nuevas formas de monumentalidad, más integradas en la ciudad actual que las precedentes. Pero si algo enseña el análisis arqueológico de la Córdoba antigua, es que con el fin del itinerario romano se cerraba el capítulo más brillante de la historia de su imagen. 